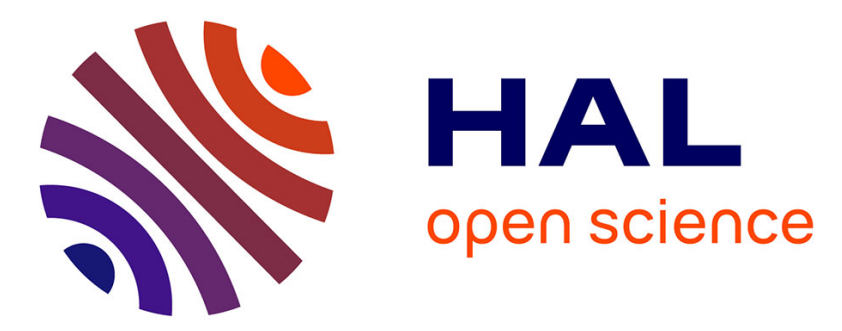

\title{
Eu(III)-Fulvic Acid Complexation: Evidence of Fulvic Acid Concentration Dependent Interactions by Time-Resolved Luminescence Spectroscopy
}

\author{
Yasmine Z. Kouhail, Marc F. Benedetti, Pascal E. Reiller
}

\section{- To cite this version:}

Yasmine Z. Kouhail, Marc F. Benedetti, Pascal E. Reiller. Eu(III)-Fulvic Acid Complexation: Evidence of Fulvic Acid Concentration Dependent Interactions by Time-Resolved Luminescence Spectroscopy. Environmental Science and Technology, 2016, 50 (7), pp.3706-3716. 10.1021/acs.est.5b05456 . cea-01299428

HAL Id: cea-01299428

https://hal-cea.archives-ouvertes.fr/cea-01299428

Submitted on 7 Apr 2016

HAL is a multi-disciplinary open access archive for the deposit and dissemination of scientific research documents, whether they are published or not. The documents may come from teaching and research institutions in France or abroad, or from public or private research centers.
L'archive ouverte pluridisciplinaire HAL, est destinée au dépôt et à la diffusion de documents scientifiques de niveau recherche, publiés ou non, émanant des établissements d'enseignement et de recherche français ou étrangers, des laboratoires publics ou privés. 


\title{
Eu(III)-FULVIC ACID COMPLEXATION: EVIDENCE OF FULVIC ACID CONCENTRATION DEPENDENT INTERACTIONS BY TIME- RESOLVED LUMINESCENCE SPECTROSCOPY.
}

\author{
Y.Z. KOUHAIL, M.F. BENEDETTI, AND P.E. REILLER
}

\begin{abstract}
Europium speciation is investigated by time-resolved luminescence spectroscopy (TRLS) in the presence of Suwannee River fulvic acid (SRFA). From complexation isotherms built at different total Eu(III) concentrations, pH values, ionic strength, and SRFA concentrations, it appears that two luminescence behaviors of Eu(III) are occurring.

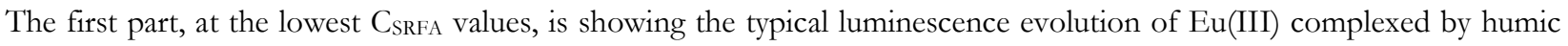
substances-i.e. the increase of the asymmetry ratio between the ${ }^{5} \mathrm{D}_{0} \rightarrow{ }^{7} \mathrm{~F}_{2}$ and ${ }^{5} \mathrm{D}_{0} \rightarrow{ }^{7} \mathrm{~F}_{1}$ transitions up to a plateau-, and the occurrence of a bi-exponential decay-the first decay being faster than free $\mathrm{Eu}^{3+}$. At higher $\mathrm{C}_{\text {SRFA }}$, a second luminescence mode is detected as the asymmetry ratio is increasing again after the previous plateau, and could correspond to the formation of another type of complex, and/or it can reflect a different spatial organization of complexed europium within the SRFA structure. The luminescence decay keeps on evolving but link to hydration number is not straightforward due to quenching mechanisms. The Eu(III) chemical environment evolution with $\mathrm{C}_{\text {SRFA }}$ is also ionic strength dependent. These observations suggest that in addition to short range interactions-intra-particulate complexation_, there might be interactions at longer range-inter-particulate repulsion-between particles that are complexing Eu(III) at high $\mathrm{C}_{\text {SRFA }}$. These interactions are not yet accounted by the different complexation models.
\end{abstract}

\section{INTRODUCTION}

The use of rare earths, and particularly the lanthanides $(\mathrm{Ln})$, is increasing in modern industry. ${ }^{1}$ Their importance in the understanding of geochemical processes, the presence of radioisotopes of lanthanides in spent nuclear fuels and radioactive wastes, and their analogy with some actinides (An) under the + III oxidation state, justify a better understanding of their environmental chemistry in waters, soils, and sediments.

Humic substances (HS), mainly composed of humic (HA) and fulvic (FA) acids are one of the main component of aquatic and soil ecosystems and are known to play an important role in the binding and transport of trace metals such as $\mathrm{Ln}(\mathrm{III}) .^{2-4}$ Because of their strong interactions with surfaces ${ }^{5}$ and their colloidal properties, ${ }^{6}$ HS may affect $\operatorname{Ln}(\mathrm{III})$ either by supporting their mobility in water, or by limiting their migration in soils and sediments. 


\section{Y.Z. KOUHAIL, M.F. BENEDETTI, AND P.E. REILLER}

HS contain a great diversity of binding sites making it difficult to define equilibrium constants for each complexation reaction. This has led to a wide variety of models. ${ }^{7}$ The most advanced models that permit to account for heterogeneity of $\mathrm{HS}$, metal loading, $\mathrm{pH}$, and ionic strength effects consider HS either as a mixture of discrete groups of sites-with different degree of correlations between these groups of sites-, e.g., Model VI-VII, ${ }^{8,9}$ or as a continuous distribution of groups of sites, e.g., NICA-Donnan. ${ }^{10}$ These kinds of models consider electrostatic phenomena, but the descriptions are somewhat different-hard sphere with a Donnan potential at the interface $v s$. permeable Donnan gel, respectively-when the structure of HS in general, and the structure of the $\mathrm{Ln}(\mathrm{III})-\mathrm{HS}$ complexes in particular, remains largely under discussion.

Some $\operatorname{Ln}(\mathrm{III})$ and $\mathrm{An}(\mathrm{III})$ show a remarkable luminescence that is linked both to symmetry of their chemical environment, ${ }^{11}$ and to the amount of water molecules in the first hydration sphere. ${ }^{12,13}$ This information can be obtained both from the evolution of the luminescence spectrum and from the decay time. This has been the basis of a vast literature on the interaction between $\mathrm{Ln}$-An(III) and HS. ${ }^{14-27}$ Particularly, it has been shown that coordination structure around a metal ion is continuously modified by HS complexation when $\mathrm{pH}$ is varying. ${ }^{20,28}$ Time resolution of the luminescence signal, through time-resolved luminescence spectroscopy (TRLS), was used to obtain complexation constants as well as structural properties.

The complexation strength of $\mathrm{Ln}(\mathrm{III})$ by HS can be considered relatively homogeneous within the series, ${ }^{29-31}$ in agreement with the strong proportion of oxygen containing functionalities of HS. ${ }^{30,32}$ Milne et al. ${ }^{33,34}$ proposed generic complexation data for $\mathrm{Ln}(\mathrm{III})$ and An(III) in the framework of the NICA-Donnan model, but the great diversity of the reported studies, and the inherent heterogeneity of the different HS samples used throughout these studies led to some problems, particularly the proposed parameters for An(III), but also between $\mathrm{Ln}(\mathrm{III})$. As an example, Milne et al. ${ }^{34}$ proposed different median affinity constants, $\log _{10} K_{\mathrm{M}^{\mathrm{n}} \text {,i, for }} \mathrm{Am}(\mathrm{III})$ and $\mathrm{Cm}(\mathrm{III})$, which is relatively surprising knowing the strong analogy between these two actinides(III), particularly regarding HS interactions. ${ }^{18}$ The correlation between NICA-Donnan parameters-Figure 1 of Milne et $a .^{34}$ —and the first hydrolysis constants of the metals, $\log _{10} * \beta^{\circ}$, also exemplify this problem: Am(III) and Cm(III) are supposed to have comparable $\log _{10} * \beta_{1}^{\circ} \approx-7,{ }^{35}$ when $\mathrm{Am}(\mathrm{III})$ appears close to $\mathrm{UO}_{2}{ }^{2+}-\log _{10}{ }^{*} \beta^{\circ}{ }_{1}$ viz: 5.8 in Figure 1 of Milne et al. $^{34}$ and $\log _{10} * \beta^{\circ}=-5.25$ in Guillaumont et al. ${ }^{35}$. Furthermore, the particular interaction of $\mathrm{HS}$ with metals vs. $\mathrm{pH}, \mathrm{CO}_{3}{ }^{2-}$ and oxalate concentration, etc., led to the

proposition of the formation of ternary complexes, ${ }^{20,36-40}$ which are not always necessary to interpret 


\section{Y.Z. KOUHAIL, M.F. BENEDETTI, AND P.E. REILLER}

experimental data within the framework of NICA-Donnan ${ }^{23,25,41}$ or Model VI-VII, ${ }^{42-44}$ but was sometimes proposed nevertheless. ${ }^{39,40}$

Cations are able to bridge two different polymer molecules, ${ }^{45}$ and this supramolecular association increases with cation valence. ${ }^{46}$ Supramolecular associations of HS are also known. ${ }^{47}$ The effect of cations on these supramolecular structures was suggested ${ }^{48}$ but needs further works. ${ }^{49-52}$ Nevertheless, the effect of $\mathrm{Eu}(\mathrm{III})$ on the aggregation of HA was shown, ${ }^{53-55}$ but the effect of HS concentration received little attention. There is therefore still a need for systematic studies of $\mathrm{Ln}(\mathrm{III})$-HS complexation at varying $\mathrm{pH}$, HS concentration, and ionic strength with spectroscopic information on the chemical environment of the metal.

Our aim is to propose an as comprehensive as possible study of the speciation of a trivalent luminescent lanthanide, $\mathrm{Eu}(\mathrm{III})$, in a wide parametric space in term of $\mathrm{pH}$ values, ionic strength, and HS concentration to better understand Ln(III)-NOM interactions and structures of NOM complexes with these trivalent cations. Time-resolved luminescence spectroscopy could be a useful tool to evidence the effect of the supramolecular structures on $\mathrm{Eu}(\mathrm{III})-\mathrm{NOM}$ complexes since it provides information on $\mathrm{Eu}$ (III) environment. We will use the Suwannee River fulvic acid (SRFA), considered as a proxy of natural organic matter reactivity, ${ }^{56}$ the relatively low UV-Visible absorption properties of which permits to use rather high concentration of FA in TRLS experiments compared to other HS extracts. ${ }^{24}$ We will take advantage of the luminescence properties of Eu(III) to characterize the $\mathrm{Eu}(\mathrm{III})-\mathrm{FA}$ complexation and to evaluate its chemical environment using TRLS.

\section{MATERIALS AND METHODS}

\subsection{REAGENTS AND CHEMICALS}

Europium(III) stock solution $\left(10^{-4} \mathrm{~mol} / \mathrm{L}\right)$ is obtained from the dissolution of $\mathrm{Eu}_{2} \mathrm{O}_{3}$ (Johnson Matthey, 99.99\%) in $\mathrm{HClO}_{4}$. All solutions are prepared using milli-Q water from a Direct Q3 Millipore. Suwannee river fulvic acid $(2 \mathrm{~S} 101 \mathrm{~F})$ is purchased from the International Humic Substances Society and used as received. The ionic strength is fixed with $\mathrm{NaClO}_{4}$ (Sigma Aldrich, $>98 \%$ ) at $0.02 \mathrm{M}, 0.1 \mathrm{M}$ and $0.5 \mathrm{M}$. The $\mathrm{pH}$ values are fixed at 4,6 , and 7 by the addition of small amounts of freshly prepared $0.1 \mathrm{M} \mathrm{NaOH}$ and/or $\mathrm{HClO}_{4}$. Measurements are done using a $\mathrm{pH}$ meter Seven Easy (Mettler Toledo) with a combined glass electrode Inlab micro, filled with $\mathrm{NaClO}_{4} 3 \mathrm{M}$ to avoid $\mathrm{KClO}_{4}$ precipitation in the frit of the electrode with the original $\mathrm{KCl}$ filling. The electrode signal in $\mathrm{mV}$ is calibrated using commercial buffer solutions ( $\mathrm{pH} 4.01,7.01$, and 10.00). 


\section{Y.Z. KOUHAIL, M.F. BENEDETTI, AND P.E. REILLER}

\subsection{TIME-RESOLVED LUMINESCENCE SPECTROSCOPY}

The experimental set-up and luminescence decay times fitting have already been described elsewhere. ${ }^{5,24,26,28}$ The 600 lines. $\mathrm{mm}^{-1}$ grating of the Acton spectrometer (slit $1 \mathrm{~mm}$ ) is used. The luminescence signal is collected during a gate width $(W)$ of $300 \mu \mathrm{s}$, at a gate delay $(D)$ of $10 \mu$ s after the excitation by the laser flash. To increase the signal to noise ratio, 1,000 to 10,000 accumulations are performed for each spectrum, the background noise is subtracted, and the luminescence is divided by the average of 100 laser shots energy before and after the acquisition, and by the number of acquisitions (accumulations).

Because of the weak energy received by the system during the experiments, photochemical reactions of humic substances ${ }^{57}$ can be excluded. The excitation wavelength is set at $\lambda_{\text {exc }}=393.7 \mathrm{~nm}$, with an energy typically less than $2 \mathrm{~mJ}$, which corresponds to the ${ }^{5} \mathrm{~L}_{6} \leftarrow{ }^{7} \mathrm{~F}_{0}$ transition of Eu(III). After inner conversion, the observed luminescence corresponds to the transitions from the ${ }^{5} \mathrm{D}_{0}$ excited state to the ground ${ }^{7} \mathrm{~F}_{\mathrm{j}}$ manifold. ${ }^{58}$ We focus our attention on three transitions: the ${ }^{5} \mathrm{D}_{0} \rightarrow{ }^{7} \mathrm{~F}_{0}$ transition $\left(\lambda_{\max }=578.8 \mathrm{~nm}\right)$, forbidden by the selection rules but apparent when Eu(III) chemical environment loses its centro-symmetry; the ${ }^{5} \mathrm{D}_{0} \rightarrow{ }^{7} \mathrm{~F}_{1}$ transition $\left(\lambda_{\max }=591.1 \mathrm{~nm}\right)$, a magnetic dipole transition; and the ${ }^{5} \mathrm{D}_{0} \rightarrow{ }^{7} \mathrm{~F}_{2}$ electric dipole transition $\left(\lambda_{\max }=615.1 \mathrm{~nm}\right)$, which is very sensitive to europium speciation, ${ }^{59}$ and known as a hypersensitive transition. The peak area ratio between the ${ }^{5} \mathrm{D}_{0} \rightarrow{ }^{7} \mathrm{~F}_{2}$ and the ${ }^{5} \mathrm{D}_{0} \rightarrow{ }^{7} \mathrm{~F}_{1}$ transitions, hereafter referred as the asymmetry ratio ${ }^{7} \mathrm{~F}_{2} /{ }^{7} \mathrm{~F}_{1}$, has often been used to estimate complexation constants, ${ }^{60}$ and structural modifications. ${ }^{5}$

\subsection{MODELING}

Modeling of Eu-SRFA interactions is performed using ECOSAT software, ${ }^{61}$ which includes speciation with inorganic ligands and humic substances through the NICA- Donnan model. ${ }^{10} \mathrm{It}$ merges the Non-Ideal Competitive Adsorption (NICA) model with a continuous distribution of sites, and a Donnan potential description to account for electrostatic interactions within the structure of HS considered as a water-permeable gel. The model accounts for electrostatic interactions, ${ }^{62}$ sites heterogeneity, non-ideality of the metal-HS complexation, and competition between metals. Milne et al. proposed generic data for HA and FA complexation with protons, ${ }^{33}$ and several metals of interest, including $\mathrm{Ln}(\mathrm{III})$ and $\mathrm{An}(\mathrm{III}) .{ }^{34}$ The inorganic side reactions of $\mathrm{Eu}(\mathrm{III})$ with $\mathrm{OH}^{-}$are implemented in the ECOSAT database. ${ }^{63}$ 


\section{Y.Z. KOUHAIL, M.F. BENEDETTI, AND P.E. REILLER}

Site densities of the two distribution of sites of SRFA- $Q_{\max , 1}$, and $Q_{\max , 2}$-, parameters representing the intrinsic heterogeneity — widths of the distributions of sites $p_{1}$ and $p_{2}-$, and generic proton parameters-non-ideality parameter $n_{\mathrm{H}^{+}, \text {i }}$, and median affinity constant $\log _{10} \tilde{K}_{\mathrm{H}^{+}, i}$-for lowaffinity type of sites—-so-called carboxylic $\mathrm{S}_{1}$ —and high-affinity type of sites-so-called phenolic $\mathrm{S}_{2}$ - proposed by Milne et al..$^{33,34}$ are recalled in Table S1 of the Supporting Information (SI).

\section{RESULTS AND DISCUSSION}

\subsection{SPECTROSCOpic Data}

$\mathrm{Eu}(\mathrm{III})$ speciation is first studied at fixed $\mathrm{pH}$ values of 4,6 , and 7 , fixed ionic strength of $0.1 \mathrm{M}$, and at varying $\mathrm{C}_{\mathrm{Eu}(\mathrm{III})}-0.5,1$, and $10 \mu \mathrm{M}$ - and SRFA concentrations — from 0 to $2,8 \mathrm{~g}_{\mathrm{SRFA}} / \mathrm{L}$. The obtained luminescence spectra shown in Figure S1 of the SI are normalized to the peak area of the ${ }^{5} \mathrm{D}_{0} \rightarrow{ }^{7} \mathrm{~F}_{1}$ transition. The complexation of Eu(III) in the system is evidenced by the increase of both the forbidden ${ }^{5} \mathrm{D}_{0} \rightarrow{ }^{7} \mathrm{~F}_{0}$ and the hypersensitive ${ }^{5} \mathrm{D}_{0} \rightarrow{ }^{7} \mathrm{~F}_{2}$ transitions. The ${ }^{5} \mathrm{D}_{0} \rightarrow{ }^{7} \mathrm{~F}_{0}$ transition appears at $\mathrm{pH}$ above 5 in the absence of SRFA, or in the presence of a slight amount of SRFA at whatever $\mathrm{pH}$ value. This typically indicates a loss of centro-symmetry compared to the aquo-complex $\mathrm{Eu}\left(\mathrm{H}_{2} \mathrm{O}\right)_{\mathrm{n}}{ }^{3+}$ and the formation of $\mathrm{Eu}(\mathrm{OH})_{\mathrm{n}}{ }^{(3-\mathrm{n})+}$ - minor under these $\mathrm{pH}$ conditions - and $\mathrm{Eu}(\mathrm{III})$ SRFA complexes.

The ${ }^{5} \mathrm{D}_{0} \rightarrow{ }^{7} \mathrm{~F}_{2}$ transition relative intensity is increasing with complexation ${ }^{59}$ - here with SRFA concentration-and shows a narrowing with metal complexation and a shift toward lower wavelengths (see Figure S1 of the SI). The variation of the relative intensity of ${ }^{5} \mathrm{D}_{0} \rightarrow{ }^{7} \mathrm{~F}_{2}$ area to the ${ }^{5} \mathrm{D}_{0} \rightarrow{ }^{7} \mathrm{~F}_{1}$ area with $\mathrm{C}_{\mathrm{SRFA}}$, provides information on $\mathrm{Eu}(\mathrm{III})$ chemical environment. It is then possible to use this evolution as a spectral titration curve. ${ }^{60}$

The evolutions of the asymmetry ratio ${ }^{7} \mathrm{~F}_{2} /{ }^{7} \mathrm{~F}_{1}$ vs. $\mathrm{C}_{\mathrm{SRFA}}$ at different $\mathrm{pH}$ values, $\mathrm{C}_{\mathrm{Eu}(\mathrm{III})}$ (Figure 1) are showing unusual features. Two different Eu(III) luminescence behaviors are evidenced. First, the peak area ratio shows an increase with $\mathrm{C}_{\mathrm{SRFA}}$ values $-\mathrm{C}_{\mathrm{SRFA}}<100 \mathrm{mg}_{\mathrm{SRFA}} / \mathrm{L}$ at $\mathrm{pH} 4, \mathrm{C}_{\mathrm{SRFA}}<40$ $\mathrm{mg}_{\mathrm{SRFA}} / \mathrm{L}$ at $\mathrm{pH} 6$, and $\mathrm{C}_{\mathrm{SRFA}}<20 \mathrm{mg}_{\mathrm{SRFA}} / \mathrm{L}$ at $\mathrm{pH} 7$-until a plateau seems to be reached. This evolution reflects the typical luminescence evolution of $\mathrm{Eu}(\mathrm{III})$ complexed by organic compounds. ${ }^{5,64-66}$ Second, after the plateau the asymmetry ratio keeps on increasing with $\mathrm{C}_{\mathrm{SRFA}}$. Chung et al. ${ }^{21}$ reported a decrease in the asymmetry ratio after the plateau with increasing $\mathrm{C}_{\mathrm{Eu}(\mathrm{III})}$ in the case of a soil FA, but we interpret this evolution as the saturation of their humic extracts and the increase of the proportion of free Eu in the system. 

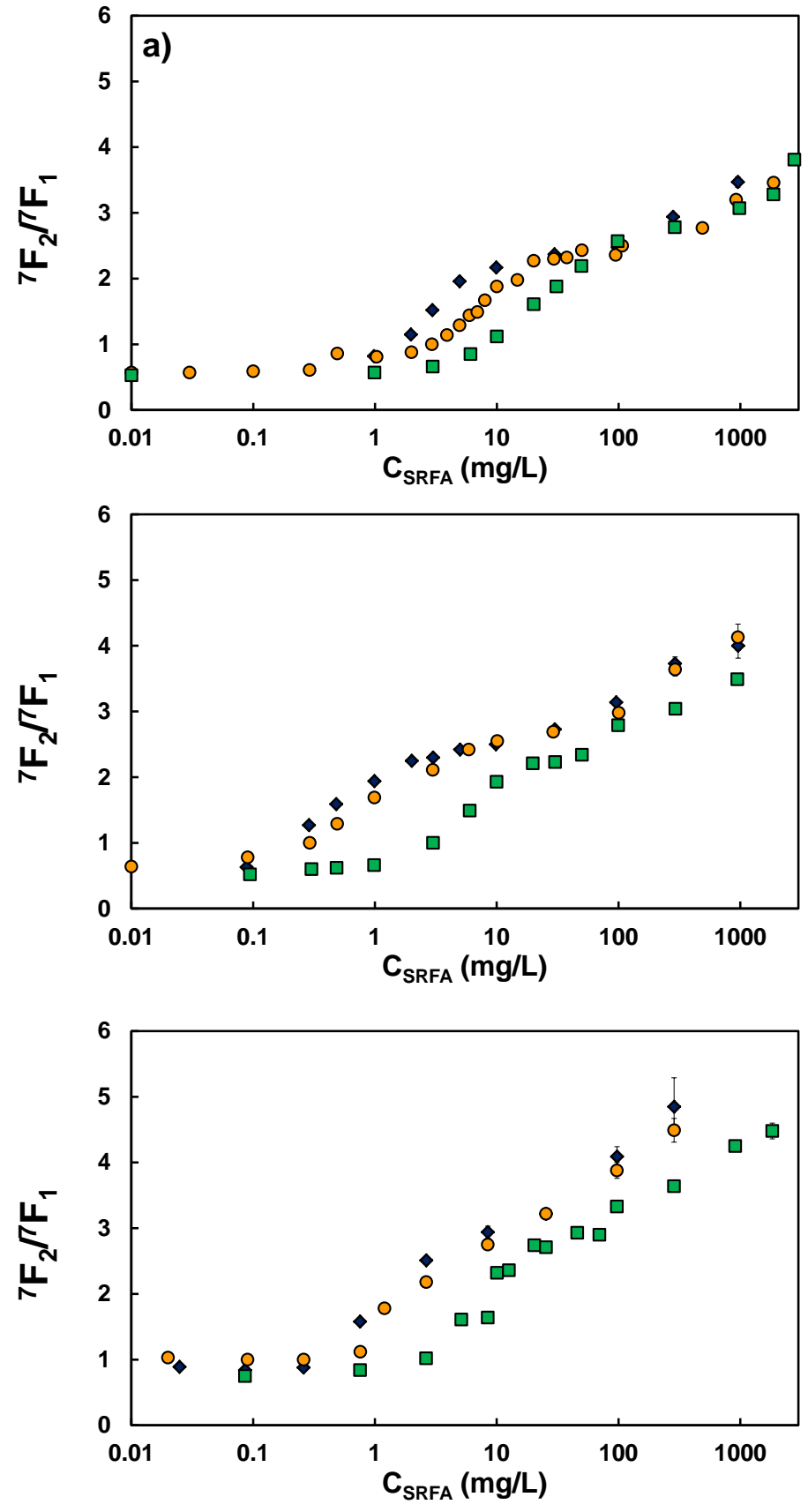

Figure 1. Evolution of ${ }^{5} \mathrm{D}_{0} \rightarrow{ }^{7} \mathrm{~F}_{2} /{ }^{5} \mathrm{D}_{0} \rightarrow{ }^{7} \mathrm{~F}_{1}$ area ratios $v s$. $\mathrm{C}_{\mathrm{SRFA}}$ at $I=0.1 \mathrm{M}, \mathrm{pH} 4$ (a); $\mathrm{pH} 6$ (b), and pH 7 (c) for $\mathrm{C}_{\mathrm{Eu}(\mathrm{III})}$ of 0.5 (blue diamonds), 1 (orange circles), and $10 \mu \mathrm{M}$ (green squares): $\lambda_{\mathrm{exc}}=393.7$ $\mathrm{nm}, D=10 \mu \mathrm{s}, W=300 \mu \mathrm{s}, 600$ lines. $\mathrm{mm}^{-1}$ grating. Error bars represent $2 \sigma$ of the area ratio using the trapezoid method. 


\section{Y.Z. KOUHAIL, M.F. BENEDETTI, AND P.E. REILLER}

\subsection{Decay Time Evolutions}

$\mathrm{Eu}(\mathrm{III})$ luminescence decay times were measured with an initial delay $D=10 \mu$ s, a gate step of 15 $\mu$ s, and a gate width $W=300 \mu$ s for $\mathrm{C}_{\mathrm{Eu}(\mathrm{III})}$ of $1 \mu \mathrm{M}$ and $10 \mu \mathrm{M}$ at $\mathrm{pH} 4,6$ and 7 (Figure S2 of the SI)—the signal at $\mathrm{C}_{\mathrm{Eu}(\mathrm{III})}=0.5 \mu \mathrm{M}$ being too weak to obtain a reliable decay time analysis.

At $\mathrm{pH} 4$ (Figure S2a of the SI), Eu(III) is showing a mono-exponential decay up $2.98 \mathrm{mg}_{\mathrm{SRFA}} / \mathrm{L}$. The $\tau$ values do not differ from the free $\mathrm{Eu}^{3+}$ one, i.e. $\tau=110 \mu \mathrm{s}{ }^{12,13}$ For $\mathrm{C}_{\mathrm{SRFA}}$ higher than 2.98 $\mathrm{mg} / \mathrm{L}$, bi-exponential decays are obtained, which could be attributed to the presence of two radiative decay processes linked to two different excited species. ${ }^{26}$ The first decay $\tau_{1}$ is faster than free $\mathrm{Eu}^{3+}$, and does not seem to vary strongly with SRFA concentration. ${ }^{5,28}$ The relationships that links the hydration number cannot be applied, as in the case of benzoic acids. ${ }^{64,66-68}$ The second decay, $\tau_{2}$, is slower than free $\mathrm{Eu}^{3+}$, and is showing two different comportments as a function of $\mathrm{C}_{\mathrm{Eu}(\mathrm{III})}$. From 2.98 up to ca. $100 \mathrm{mg}_{\mathrm{SRFA}} / \mathrm{L}$-i.e., the $\mathrm{C}_{\mathrm{SRFA}}$ value where all the ${ }^{7} \mathrm{~F}_{1} /{ }^{7} \mathrm{~F}_{2}$ evolution are merging in Figure 1 -, the $\tau_{2}$ value is increasing up to $c a .180 \mu \mathrm{s}$ whatever the $\mathrm{C}_{\mathrm{Eu}(\mathrm{III})}$. This is the typical comportment of $\mathrm{Eu}(\mathrm{III})$ complexed by HS, which can be interpreted as the substitution of inner-sphere water molecules by SRFA functionalities. The $\tau_{2}$ value $c a .175 \mu \mathrm{s}$ is in agreement with the evolution observed for Eu-HS complexes. ${ }^{24}$ The application of the relationship from Kimura and Choppin ${ }^{13}$ is debatable, but would indicate the loss of ca. $3.6 \pm 0.5$ water molecules. At higher $\mathrm{C}_{\mathrm{SRFA}}$ values, the decay time evolutions are more intricate to interpret. If $\tau_{2}$ values keep on increasing for $\mathrm{C}_{\mathrm{Eu}(\mathrm{III})}=1$ $\mu \mathrm{M}$-i.e., $\tau_{2} c a .235 \mu$ s and a loss of $c a .5 .2 \pm 0.5$ water molecules - they also seem to attain a plateau. Conversely, $\tau_{2}$ seems to decrease for $\mathrm{C}_{\mathrm{Eu}(\mathrm{III})}=10 \mu \mathrm{s}$. The application of the relationship from Kimura and Choppin ${ }^{13}$ has no sense here as it would indicate a "gain" of ca. $1.4 \pm 0.5$ water molecules between 100 and $1000 \mathrm{mg}_{\text {SRFA }} / \mathrm{L}$, when the increases in both ${ }^{5} \mathrm{D}_{0} \rightarrow{ }^{7} \mathrm{~F}_{0}$ area and asymmetry ratio (Figure 1) indicate a continuing change in the complexation environment of $\mathrm{Eu}(\mathrm{III})$. The combination of the apparent plateau for $\mathrm{C}_{\mathrm{Eu}(\mathrm{III})}=1 \mu \mathrm{M}$ and the decrease at $10 \mu \mathrm{M}$, may lead to a possible dynamic quenching, the origin of which is not possible to determine and would require further investigations.

At $\mathrm{pH} 6$ (Figure S2b of the SI), only mono-exponential decays can be fitted for $\mathrm{C}_{\mathrm{SRFA}}$ lower than $30 \mathrm{mg} / \mathrm{L}$ There is only a very slight increase in the $\tau$ values from $c a .100$ to ca. $140 \mu \mathrm{s}$-loss of $c a .2 .2$ \pm 0.5 water molecules. Bi-exponential decays are obtained for $\mathrm{C}_{\mathrm{SRFA}}$ higher than $30 \mathrm{mg}_{\mathrm{SRFA}} / \mathrm{L}$ for $\mathrm{C}_{\mathrm{Eu}(\mathrm{III})}$ of 1 and $10 \mu \mathrm{M}$ up to $1 \mathrm{~g}_{\mathrm{SRFA}} / \mathrm{L}$. One also note the difference between $\mathrm{C}_{\mathrm{Eu}(\mathrm{III})}$, which is 


\section{Y.Z. KOUHAIL, M.F. BENEDETTI, AND P.E. REILLER}

reminiscent of the evolution at $\mathrm{pH} 4$ and would also indicate a quenching mechanism. The final situation at $\mathrm{C}_{\mathrm{Eu}(\mathrm{III})}$ and $\mathrm{C}_{\mathrm{SRFA}}=1 \mathrm{~g}_{\mathrm{SRFA}} / \mathrm{L}$ would indicate the loss of ca. $5.8 \pm 0.5$ water molecules.

At pH 7 (Figure S2c of the SI), mono-exponential decays are first obtained at lower $\mathrm{C}_{\mathrm{SRFA}}$. Biexponential decays are obtained for $\mathrm{C}_{\mathrm{SRFA}}$ higher than $3 \mathrm{mg}_{\mathrm{SRFA}} / \mathrm{L}$ for $\mathrm{C}_{\mathrm{Eu}(\mathrm{III})}$ of 1 and $10 \mu \mathrm{M}$. The obtained decays are showing a slight increase in $\tau_{1}$ and a stronger continuous increase in $\tau_{2}$ up to 285 $\mu$ s for $\mathrm{C}_{\mathrm{Eu}(\mathrm{III})}=10 \mu \mathrm{M}$-loss of $c a .6 .0 \pm 0.5$ water molecules. Both $\mathrm{Eu}(\mathrm{III})$ concentration seem to follow the same trend even if the $\tau_{2}$ value for $\mathrm{C}_{\mathrm{Eu}(\mathrm{III})}=10 \mu \mathrm{M}$ and $\mathrm{C}_{\mathrm{SRFA}}=1 \mathrm{~g}_{\mathrm{SRFA}} / \mathrm{L}$ is clearly below the trend. The possible quenching mechanism seems to be less operant here.

Nevertheless, the decay time evolutions seem to confirm that different environments are present at different $\mathrm{C}_{\text {SRFA }}$. The estimation of hydration sphere here is constrained by the relationship from Kimura and Choppin ${ }^{13}$, the validity of which has not been demonstrated up to now in these systems.

\subsection{EFFECT OF IONIC STRENGTH.}

In order to improve the understanding of the second mode in the complexation isotherms, we performed experiments at $\mathrm{pH} 7$ and various ionic strengths $\left(I=0.02,0.1\right.$, and $\left.0.5 \mathrm{M} \mathrm{NaClO}_{4}\right)$, which asymmetry ratios' evolutions are shown in Figure 2. First, before the plateau, i.e., $<10 \mathrm{mg}_{\mathrm{SRFA}} / \mathrm{L}$, the complexation is decreasing as expected with ionic strength, ${ }^{10,69}$ whilst a reverse influence is shown at higher $\mathrm{C}_{\text {SRFA }}$. This second part, where the peak area ratio is still increasing, means that the chemical environment of $\mathrm{Eu}(\mathrm{III})$ is ionic strength dependent. If one considers that the decrease of the

asymmetry ratio with ionic strength at low $\mathrm{C}_{\mathrm{SRFA}}$ indicates a typical weaker binding, ${ }^{18,69,70}$ then one can also consider that the increase in asymmetry ratio at higher $\mathrm{C}_{\mathrm{SRFA}}$ with ionic strength indicates a stronger binding environment. This was never reported in previous studies focusing on metalorganic matter speciation. ${ }^{24}$ 


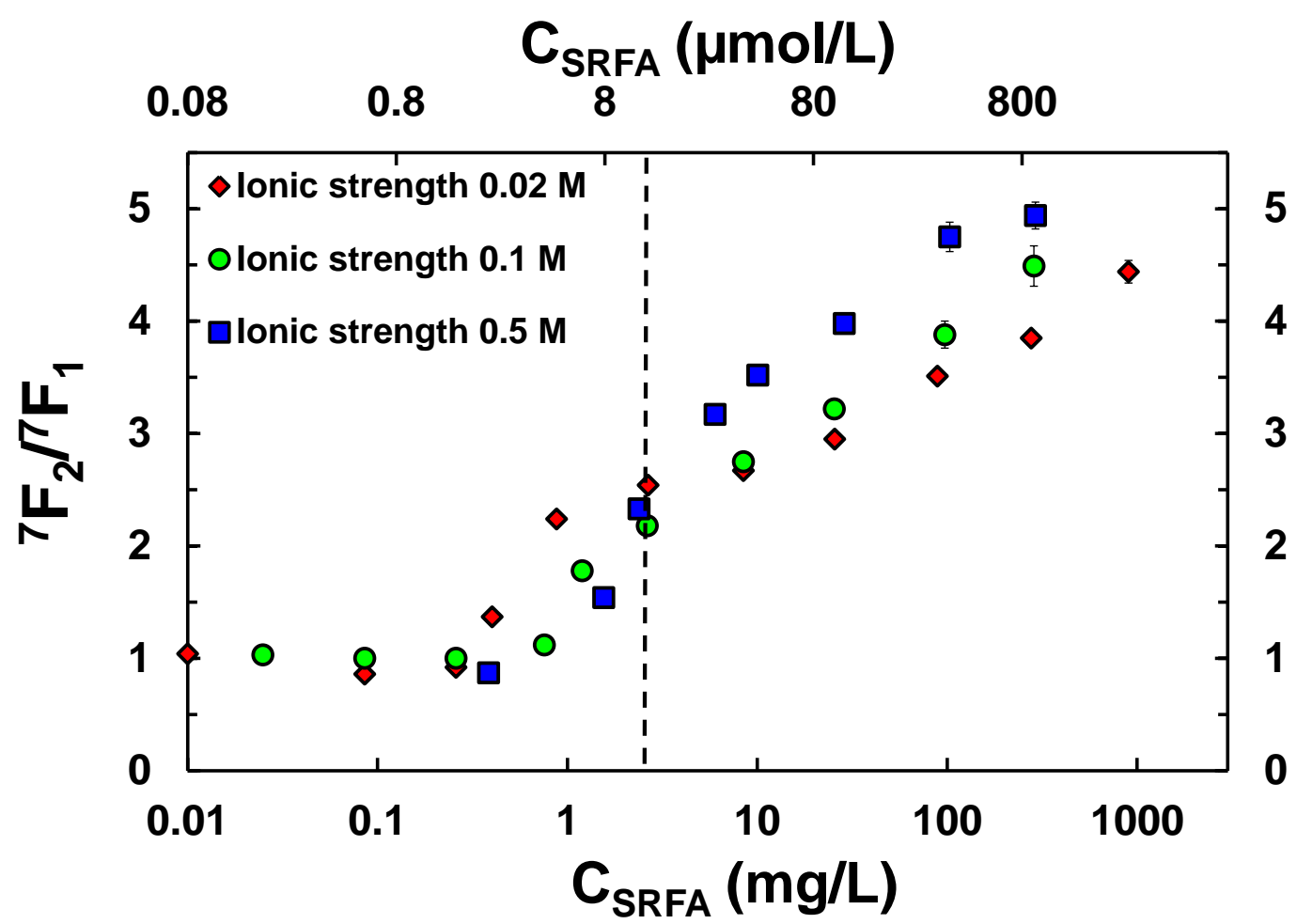

Figure 2. Evolution of ${ }^{5} \mathrm{D}_{0} \rightarrow{ }^{7} \mathrm{~F}_{2} /{ }^{5} \mathrm{D}_{0} \rightarrow{ }^{7} \mathrm{~F}_{1}$ area ratios vs. $\mathrm{C}_{\text {SRFA }}$ the ionic strength $(I=0.02 \mathrm{M}$, red diamonds; $I=0.1 \mathrm{M}$, green circles; $I=0.5 \mathrm{M}$, blue squares) at $\mathrm{C}_{\mathrm{Eu}(\mathrm{III})}$ of $1 \mu \mathrm{M}$ and $\mathrm{pH}$ 7. Dashed line corresponds to the inversion of the ionic strength trend.

\subsection{Simulation AND MODELING.}

For a better understanding of the second mode in complexation isotherms, simulations of $\mathrm{Eu}(\mathrm{III})$ SRFA complexation are done using NICA-Donnan generic parameters ${ }^{34}$ for $\mathrm{C}_{\mathrm{Eu}(\mathrm{III})}$ of $0.5,1$ and $10 \mu \mathrm{M}$, at $I=0.1 \mathrm{M}$ (Figure S3 of the SI). Eu(III) is increasingly fixed to SRFA, mostly to $\mathrm{S}_{1}$ sites at $\mathrm{pH}$ 4. The proportion of $\mathrm{Eu}(\mathrm{III})$ bound to $\mathrm{S}_{2}$ sites is increasing with $\mathrm{pH}$. The total complexation is expected around $\mathrm{C}_{\mathrm{SRFA}}=100 \mathrm{mg}_{\mathrm{SRFA}} / \mathrm{L}$ for $\mathrm{pH} 4, \mathrm{C}_{\mathrm{SRFA}}=40 \mathrm{mg}_{\mathrm{SRFA}} / \mathrm{L}$ for $\mathrm{pH} 6$, and $\mathrm{C}_{\mathrm{SRFA}}=20$ $\mathrm{mg}_{\mathrm{SRFA}} / \mathrm{L}$ for $\mathrm{pH}$ 7. No account for mixed $\mathrm{Eu}(\mathrm{OH})_{\mathrm{n}} \mathrm{FA}$ complexes is needed in these simulations $v s$. $\mathrm{pH}$. Nevertheless, it can be recalled that mixed $\mathrm{Fe}(\mathrm{OH}) \mathrm{HA}$, and $\mathrm{Al}(\mathrm{OH}) \mathrm{HA}$ complexes was proposed in the framework of NICA-Donnan ${ }^{40}$ or Model VI, ${ }^{39}$ respectively. No further modification of the speciation is expected from the calculation at higher $\mathrm{C}_{\mathrm{SRFA}}$. Therefore, the further increase of asymmetry ratio should correspond to another complexation/fixation mode not accounted for by any available model, yet. 


\section{Y.Z. KOUHAIL, M.F. BENEDETTI, AND P.E. REILLER}

It is then possible to compare our dataset to the prediction of the NICA-Donnan model. First, the asymmetry ratios are used as indicators of the proportion of Eu(III) complexed to SRFA (Figure S4 of the SI). ${ }^{60}$ The asymmetry ratio evolves with the metal to SRFA concentration ratio. When SRFA is not present in the system, the asymmetry ratio is the one for the Eu(III) aquo-complex. When the asymmetry ratio is reaching a plateau at $\mathrm{pH} 4$ (Figure S4 of the SI), this suggests that all of Eu(III) is complexed to SRFA. This evolution is used as a spectral titration curve to calculate proportions of $\mathrm{Eu}$ (III) bound to SRFA (Figure 3a). ${ }^{60}$ At $\mathrm{pH}$ 6, the existence of a plateau is less clear (Figure 1b) but seems to occur for $\mathrm{C}_{\mathrm{SRFA}}$ of $10 \mathrm{mg}_{\mathrm{SRFA}} / \mathrm{L}$ for $\mathrm{C}_{\mathrm{Eu}(\mathrm{III})}$ of $0.5 \mu \mathrm{M}$ and $1 \mu \mathrm{M}$, and for $\mathrm{C}_{\mathrm{SRFA}}$ of $30 \mathrm{mg}_{\mathrm{SRFA}} / \mathrm{L}$ for $\mathrm{C}_{\mathrm{Eu}(\mathrm{III})}$ of $10 \mu \mathrm{M}$. These values are supported by our previous simulations (vide supra, Figure S3 of the SI). At pH 6, Eu(III) is totally bound to the SRFA for concentrations ca. 10 $\mathrm{mg}_{\mathrm{SRFA}} / \mathrm{L}$ for $\mathrm{C}_{\mathrm{Eu}(\mathrm{III})}$ of $0.5 \mu \mathrm{M}$, and $1 \mu \mathrm{M}$, and for concentration $c a .30 \mathrm{mg}_{\mathrm{SRFA}} / \mathrm{L}$ for $\mathrm{C}_{\mathrm{Eu}(\mathrm{III})}$ of $10 \mu \mathrm{M}$. At pH 7 (Figure 1c), the end of the first complexation mode is set as for $\mathrm{pH}$ 6, when Eu(III) is fully bound to SRFA in our previous simulations, for concentrations of $2.6 \mathrm{mg}_{\mathrm{SRFA}} / \mathrm{L}$ for $\mathrm{C}_{\mathrm{Eu}(\mathrm{III})}$ of 0.5 and $1 \mu \mathrm{M}$ and $10 \mathrm{mg}_{\mathrm{SRFA}} / \mathrm{L}$ for $\mathrm{C}_{\mathrm{Eu}(\mathrm{III})}$ of $10 \mu \mathrm{M}$.

For a better fit, NICA-Donnan parameters for Eu(III)-SRFA binding are adjusted. The adjustment of $\mathrm{Eu}$ (III) binding parameters for $\mathrm{S}_{1}$ sites is done at $\mathrm{pH} 4$ only, because at higher $\mathrm{pH}$ values, due the presence of hydrolyzed species of Eu(III), the asymmetry ratio at low SFRA concentration could not correspond to free $\mathrm{Eu}^{3+}$. Thus, the adjusted parameters for the low proton affinity sites $\mathrm{S}_{1}$ at $\mathrm{pH} 4$ are used at $\mathrm{pH} 6$ and 7 to adjust the parameters for the high proton affinity sites $\mathrm{S}_{2}$.

The proportion of $\mathrm{Eu}(\mathrm{III})-\mathrm{SRFA}$ complex for $\mathrm{C}_{\mathrm{Eu}(\mathrm{III})}$ of $0.5,1$, and $10 \mu \mathrm{M}$ at $\mathrm{pH} 4,6$, and 7, and the modeling of $\mathrm{Eu}(\mathrm{III})$ bound to SRFA are shown in Figure 3. NICA-Donnan parameters for proton and $\mathrm{Eu}(\mathrm{III})$ binding to SRFA used in the model are presented in Table S1 of the SI. The model is slightly underestimating the complexation for $\mathrm{C}_{\mathrm{Eu}(\mathrm{III})}=0.5 \mu \mathrm{M}$ at $\mathrm{pH} 4$, but it is still in fair agreement with experimental data. It is worthy to notice in Table S1 of the SI that compared to generic parameters, Eu(III) complexation by SRFA is less important-lower $\log _{10} \tilde{K}_{\mathrm{Eu}^{3+}, 1}$ - and the distribution is more heterogeneous for $\mathrm{S}_{1}$ sites-lower $n_{\mathrm{Eu}^{3+}, 1}$, and that the complexation is

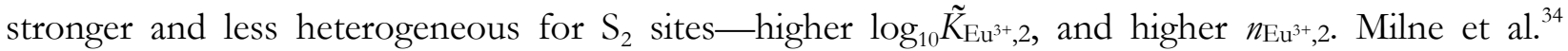
proposed correlation between $n_{\mathrm{M}^{\mathrm{n}}, \mathrm{i}}$ and $n_{\mathrm{M}^{\mathrm{n}+}, \mathrm{i}} \times \log _{10} \tilde{K}_{\mathrm{M}^{n+}, \mathrm{i}} v$ s. $\log _{10} * \beta^{\circ}{ }_{1}$. As it can be anticipated from the very little difference between the simulations using generic parameters ${ }^{34}$ and the modeling of our data, it can be seen in Table S1 of the SI that $n_{\mathrm{Eu}^{3+}, 1} \times \log _{10} \tilde{K}_{\mathrm{Eu}^{3+}, 1}$ are in good agreement. Nevertheless, 
it seems that $n_{\mathrm{Eu}^{3+}, 2} \times \log _{10} \tilde{K}_{\mathrm{Eu}^{3+}, 2}$ is higher in our case leading to a slightly higher complexation than anticipated.
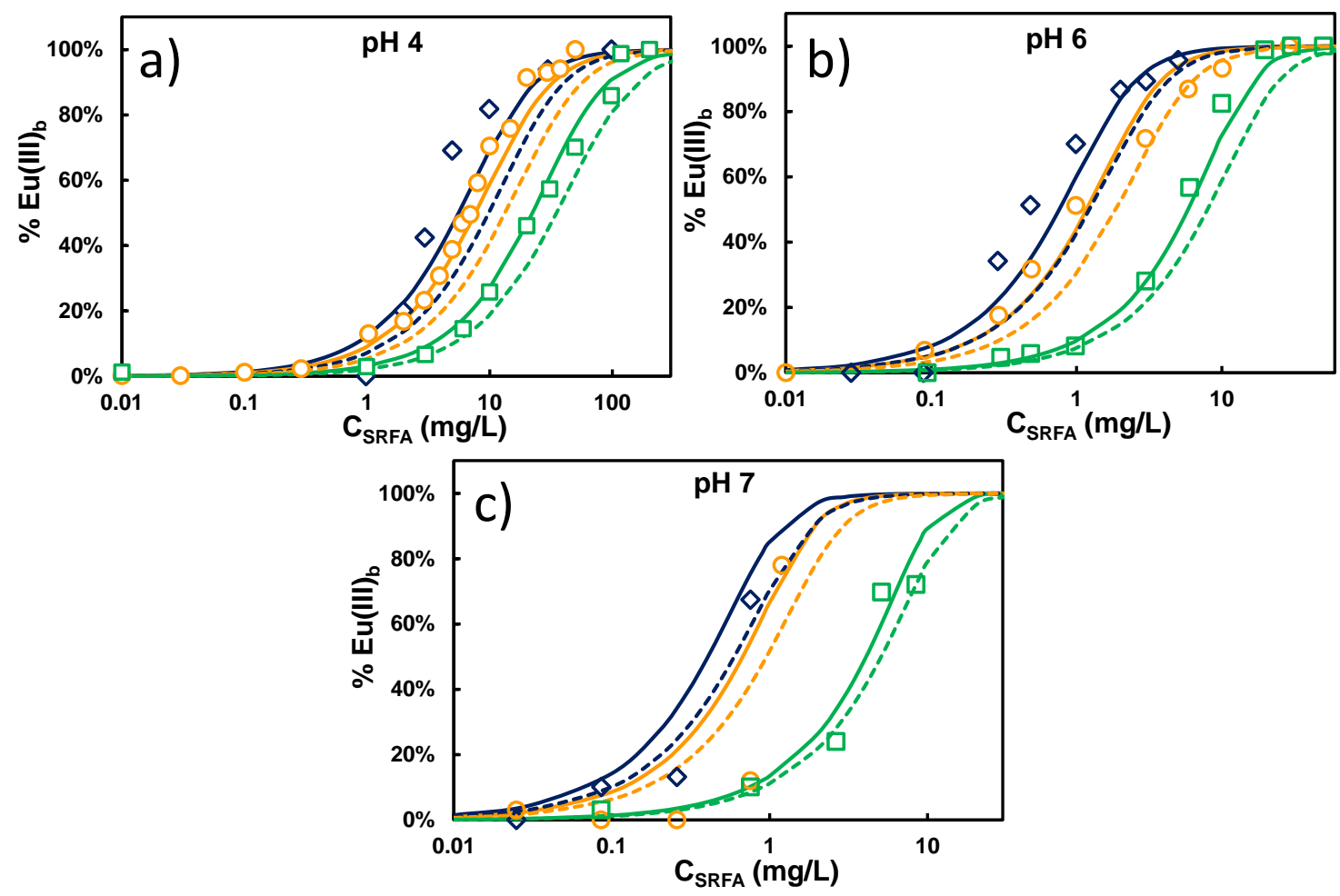

Figure 3. Proportion of $\mathrm{Eu}(\mathrm{III})$ bound to SRFA for $\mathrm{Eu}(\mathrm{III})$ concentrations of $0.5 \mu \mathrm{M}$ (blue diamonds), $1 \mu \mathrm{M}$ (orange circles) and $10 \mu \mathrm{M}$ (green squares) at $\mathrm{pH} 4$ (a), 6 (b), and 7 (c). The dashed lines are the simulations and the solid lines are the results of our modeling of Eu(III) bound to SRFA. Adjusted and generic NICA Donnan parameters are given in Table S1 of the SI.

\section{5. $\mathrm{Eu}(\mathrm{III})-$ SRFA INTERACTIONS.}

It was possible to satisfactorily describe Eu(III)-SRFA interactions that occur in the first parts of the isotherms with the NICA-Donnan model. The increase in asymmetry ratio at higher $\mathrm{C}_{\mathrm{SRFA}}$ with ionic strength (Figure 2), which indicates a change in the complexation environment, still needs to be cleared. The influence of varying metal concentration with constant HS concentration-see Hummel et al. ${ }^{70}$ and references therein-is directly accounted for within the NICA-Donnan model, ${ }^{71}$ and is not in play here. Assumptions are made, which may not necessarily exclude each other, regarding this original asymmetry ratio evolution at the higher $\mathrm{C}_{\mathrm{SRFA}}$ : (i) it may correspond to the formation of another type of complex, e.g., strong sites $v$ s. weak sites or a 1:2 complex $^{72-74}$; (ii) and/or 


\section{Y.Z. KOUHAIL, M.F. BENEDETTI, AND P.E. REILLER}

it can reflect a different spatial organization of the complexed europium constrained by a change in the SRFA structure. As the UV-Visible absorption of HS decreases rather monotonously with wavelength, one may also propose higher auto absorption of the ${ }^{5} \mathrm{D}_{0} \rightarrow{ }^{7} \mathrm{~F}_{1}$ transition wavelength span compared to the ${ }^{5} \mathrm{D}_{0} \rightarrow{ }^{7} \mathrm{~F}_{2}$ transition one with $\mathrm{C}_{\text {SRFA }}$. The fact that the second increase occurs at lower $\mathrm{C}_{\mathrm{SRFA}}$ with $\mathrm{pH}$ permits to exclude this hypothesis.

A possible explanation may rely in the influence of ionic strength on complexation and adsorption. Following the Debye-Hückel theory, the decrease in complexation with ionic strength at low $\mathrm{C}_{\mathrm{SRFA}}$ is in line with the evolution of the activity coefficient with the reciprocal of the Debye length $(\kappa) .{ }^{75}$ This indicates that at low $\mathrm{C}_{\mathrm{SRFA}}$ the complexation occurs with rather isolated functional groups in the SRFA structure. At higher $\mathrm{C}_{\mathrm{SRFA}}$ one can consider the interaction between SRFA entities as supramolecular associations of fulvic acid particles. ${ }^{47,49}$ The variation of the hydrodynamic radius $\left(\mathrm{R}_{\mathrm{H}}\right)$ with ionic strength of the smallest entities of HS, including SRFA, has given contrasted results. ${ }^{76,77}$ When d'Orlyé and Reiller ${ }^{77}$ did not evidence a clear increase in $\mathrm{R}_{\mathrm{H}}$ with ionic strength at $\mathrm{pH} 10$ in Taylor dispersion analysis, Domingos et al. ${ }^{76}$ reported a small decrease of diffusion coefficient of SRFA—small increase in $\mathrm{R}_{\mathrm{H}}$ - with ionic strength between $\mathrm{pH} 2$ and 8 in fluorescence correlation spectroscopy. This latter result was interpreted as a reduction of both intramolecular and intermolecular repulsion. Decreasing intramolecular repulsion will lead to molecular compression, while decreasing intermolecular repulsion can increase aggregation. It has also been shown that contrary to simple organics - and commonly to polyelectrolytes ${ }^{78,79}$-, adsorption of humic substances onto minerals is increasing with ionic strength. ${ }^{5,80}$ Even if this effect is much weaker for FA compared to $\mathrm{HA}^{81}$ this means that HS entities in general can approach at shorter distances to each other in solution with increasing ionic strength. Following the Gouy-Chapman theory, Eu(III)bearing SRFA entities can more easily approach each other with increasing ionic strength. The second part of the asymmetry ratio increase could therefore be due to the formation of complexes with higher stoichiometry between complexation sites that are not located on the same HS entity or "particle". This suggests that there might be electrostatic driven interactions between fulvic acid sites in particles that are typically complexing $\mathrm{Eu}(\mathrm{III})$ - intra-particulate complexation mode-, and form $\mathrm{Eu}(\mathrm{III})$-bridged complexes in the second part of the asymmetry ratio evolution-inter-particulate complexation mode. We can also notice that in complexation isotherms at $\mathrm{pH} 7$ and various ionic strengths (Figure 2) the metal to ionized FA sites concentration ratio equals 10 at the boundary between the two-luminescence modes. In the second mode, we can assume that Eu(III)-bridged complexes are formed because of the decreasing metal to ionized FA sites concentration ratio.

$$
-12-
$$




\section{Y.Z. KOUHAIL, M.F. BENEDETTI, AND P.E. REILLER}

The formation of 1:2 stoichiometry complexes was suggested by Bertha and Choppin ${ }^{73}$ who studied interactions of HS (HA and FA) with Eu(III) and Am(III). Their results, using Schubert's method to determine binding constants, suggest the formation of 1:1 and 1:2 Eu-HS complexes from slope analyses of the variation of the distribution coefficient with humic acid concentration. At pH 4.5 Bertha and Choppin ${ }^{73}$ proposed that Eu(III) is bound simultaneously by one or two carboxylate groups. In our study we could interpret our spectroscopically observed evolutions as the successive formation of the 1:1 and 1:2 Eu(III)-SRFA complexes. The ionic strength effect in complexation isotherms suggests that complexation sites may not be located on the same fulvic acid particle. Such interactions are not yet accounted for in any model describing metal-HS interactions, and would require either complete rewriting of the models, or adaptation of the existing models to this not yet noticed effect.

Within the NICA-Donnan model framework, the Donnan volume $\mathrm{V}_{\mathrm{D}}$ is optimized to build the acid-base titration master curves. It decreases with ionic strength following an empirical relationship. ${ }^{62}$ The Donnan potential $\psi_{\mathrm{D}}$ inside this volume is assumed negative and constant inside, and nil outside the particle-or water-permeable Donnan gel. It can be calculated from the ratio of the activity of ions inside and outside the Donnan gel, and from the charge density inside the gel, so that the decrease in complexation with ionic strength is linked to a decrease in the negative value of $\mathrm{q} / \mathrm{V}_{\mathrm{D}}$ and $\psi_{\mathrm{D}} \cdot{ }^{10}$ One could then think that the increase of $\mathrm{Eu}(\mathrm{III})$ association at high $\mathrm{C}_{\mathrm{SRFA}}$ with ionic strength could be linked to an apparent increase in the negative value $q / V_{D}$ and $\psi_{D}$. The verification of this hypothesis implies the determination of the size of Eu(III)-SRFA complexes at varying $\mathrm{pH}$, Eu and SRFA concentrations, and ionic strength. It is nevertheless, worthy to recall that, as already discussed in Benedetti et al., ${ }^{62}$ the Donnan model seems not to be very realistic for FA because the changes in Donnan volumes as a function of ionic strength are too large.

Another possibility is the account of an interfacial potential, as a double layer spreading outside the

Donnan gel as proposed by Saito et al., ${ }^{82,83}$ which should be implemented to be effective at high $\mathrm{C}_{\mathrm{SRFA}}$ and should mostly be ineffective at low $\mathrm{C}_{\mathrm{SRFA}}$ in order to represent the already successful modeling obtained up to now within the framework of NICA-Donnan.

\section{SUPPORTING INFORMATION.}

The supporting information contains four Figures and one Table. One Figure shows Eu(III)SRFA normalized luminescence spectra to the ${ }^{5} \mathrm{D}_{0} \rightarrow{ }^{7} \mathrm{~F}_{1}$ transition at $0.1 \mathrm{M} \mathrm{NaClO}_{4}$ and $\mathrm{C}_{\mathrm{Eu}(\mathrm{III})}=1$ 


\section{Y.Z. KOUHAIL, M.F. BENEDETTI, AND P.E. REILLER}

$\mu \mathrm{M}$ at $\mathrm{pH}$ 4, 6 and 7. One Figure shows luminescence decay times of $\mathrm{Eu}(\mathrm{III})$ at $\mathrm{pH} 4,6$ and 7 depending on fulvic concentration for $\mathrm{Eu}(\mathrm{III})$ concentrations of $1 \mu \mathrm{M}$ and $10 \mu \mathrm{M}$. One Figure shows the simulation of Eu bound to SRFA and NICA-Donnan parameters using generic parameters. One Figure shows the transformation of asymmetry ration in proportion of $\mathrm{Eu}(\mathrm{III})$ bound to the fulvic acid. One Table is showing the NICA-Donnan generic parameters for simulation, and the NICADonnan parameters obtained from modeling. This material is available free of charge via the Internet at http://pubs.acs.org.

\section{ACKNOWLEDGMENT}

Pr. Jose Paulo Pinheiro and Dr. Rute Domingos are acknowledged for useful conversations and suggestions. This work was partly financed by the inner RCHIM project within the RSTB program from CEA.

\section{REFERENCES}

1. Binnemans K., Jones P.T., Blanpain B., van Gerven T., Yang Y.X., Walton A., and Buchert M. (2013). Recycling of rare earths: a critical review. Journal of Cleaner Production 51, 1-22; DOI 10.1016/j.jclepro.2012.12.037.

2. McCarthy J.F., Czerwinski K.R., Sanford W.E., Jardine P.M., and Marsh J.D. (1998). Mobilization of transuranic radionuclides from disposal trenches by natural organic matter. Journal of Contaminant Hydrology 30 (1-2), 49-77; DOI 10.1016/S0169-7722(97)00032-6.

3. McCarthy J.F., Sanford W.E., and Stafford P.L. (1998). Lanthanide field tracers demonstrate enhanced transport of transuranic radionuclides by natural organic matter. Environmental Science \& Technology 32 (24), 3901-3906; DOI 10.1021/es971004f.

4. Bryan N.D., Abrahamsen L., Evans N., Warwick P., Buckau G., Weng L.P., and van Riemsdijk W.H. (2012). The effects of humic substances on the transport of radionuclides: recent improvements in the prediction of behaviour and the understanding of mechanisms. Applied Geochemistry 27 (2), 378-389; DOI 10.1016/j.apgeochem.2011.09.008.

5. Janot N., Benedetti M.F., and Reiller P.E. (2013). Influence of solution parameters on europium(III), $\alpha-\mathrm{Al}_{2} \mathrm{O}_{3}$, and humic acid interactions: macroscopic and time-resolved laserinduced luminescence data. Geochimica et Cosmochimica Acta 123, 35-54; DOI 10.1016/j.gca.2013.08.038.

6. Jones M.N., and Bryan N.D. (1998). Colloidal properties of humic substances. Advances in Colloid and Interface Science 78 (1), 1-48; DOI 10.1016/S0001-8686(98)00058-X.
7. Hummel W. (1997) Binding models for humic substances. In Modelling in Aquatic Chemistry, Grenthe I. and Puigdomènech I., Eds. OECD's Nuclear Energy Agency: Paris, France, pp 153-206.

8. Tipping E. (1998). Humic ion-binding model VI: an improved description of the interactions of protons and metal ions with humic substances. Aquatic Geochemistry 4 (1), 3-48; DOI 10.1023/A:1009627214459.

9. Tipping E., Lofts S., and Sonke J.E. (2011). Humic ionbinding Model VII: a revised parameterisation of cationbinding by humic substances. Environmental Chemistry 8 (3), 225-235; DOI 10.1071/EN11016.

10. Kinniburgh D.G., van Riemsdijk W.H., Koopal L.K., Borkovec M., Benedetti M.F., and Avena M.J. (1999). Ion binding to natural organic matter: competition, heterogeneity, stoichiometry and thermodynamic consistency. Colloids and Surfaces A: Physicochemical and Engineering Aspects 151 (1-2), 147166; DOI 10.1016/S0927-7757(98)00637-2.

11. Bünzli J.-C.G. (1989) Luminescent probes. In Lanthanides Probe in Life, Chemical and Earth Sciences - Theory and Practice, Bünzli J.-C.G. and Choppin G.R., Eds. Elsevier: Amsterdam, The Netherlands, pp 219-293.

12. Horrocks W.D., Jr., and Sudnick D.R. (1979). Lanthanide ion probes of structure in biology. Laser-induced luminescence decay constants provide a direct measure of the number of metal-coordinated water-molecules. Journal of the American Chemical Society 101 (2), 334-340; DOI 10.1021/ja00496a010. 


\section{Y.Z. KOUHAIL, M.F. BENEDETTI, AND P.E. REILLER}

13. Kimura T., and Choppin G.R. (1994). Luminescence study on determination of the hydration number of $\mathrm{Cm}(\mathrm{III})$. Journal of Alloys and Compounds 213-214, 313-317; DOI 10.1016/09258388(94)90921-0.

14. Bidoglio G., Grenthe I., Qi P., Robouch P., and Omenetto N. (1991). Complexation of $\mathrm{Eu}$ and $\mathrm{Tb}$ with fulvic acids as studied by time-resolved laser-induced fluorescence. Talanta 38 (9), 999-1008; DOI 10.1016/0039-9140(91)80316-R.

15. Moulin C., Decambox P., Mauchien P., Moulin V., and Theyssier M. (1991). On the use of laser-induced timeresolved spectrofluorometry for interaction studies between organic matter and actinides: application to curium. Radiocbimica Acta 52-53, 119-125; DOI 10.1524/ract.1991.5253.1.119.

16. Kim J.I., Wimmer H., and Klenze R. (1991). A study of curium(III) humate complexation by time resolved laser induced fluorescence spectroscopy (TRLFS). Radiochimica Acta 54 (1), 35-41; DOI 10.1524/ract.1991.54.1.35.

17. Yoon T.H., Moon H., Park Y.J., and Park K.K. (1994). Investigation of metal binding sites on soil fulvic acid using $\mathrm{Eu}(\mathrm{III})$ luminescence spectroscopy. Environmental Science \& Technology 28 (12), 2139-2146; DOI 10.1021/es00061a023.

18. Czerwinski K.R., Kim J.I., Rhee D.S., and Buckau G. (1996). Complexation of trivalent actinides ions $\left(\mathrm{Am}^{3+}, \mathrm{Cm}^{3+}\right)$ with humic acids: the effect of ionic strength. Radiochimica Acta $\mathbf{7 2}$ (4), 179-187; DOI 10.1524/ract.1996.72.4.179.

19. Moulin C., Wei J., van Iseghem P., Laszak I., Plancque G., and Moulin V. (1999). Europium complexes investigations in natural waters by time-resolved laser-induced fluorescence. Analytica Cbimica Acta 396 (2-3), 253-261; DOI 10.1016/S0003-2670(99)00427-4.

20. Morgenstern M., Klenze R., and Kim J.I. (2000). The formation of mixed-hydroxo complexes of $\mathrm{Cm}(\mathrm{III})$ and $\mathrm{Am}(\mathrm{III})$ with humic acid in the neutral $\mathrm{pH}$ range. Radiochimica Acta 88 (1), 7-16; DOI 10.1524/ract.2000.88.1.007.

21. Chung K.H., Lee W., Cho Y., Choi G.S., and Lee C.W. (2005). Comparison of synchronous and laser-induced fluorescence spectroscopy applied to the $\mathrm{Eu}(\mathrm{III})$-fulvate complexation. Talanta $\quad \mathbf{6 5} \quad$ (2), 389-395; DOI 10.1016/j.talanta.2004.06.026.

22. Kumke M.U., Eidner S., and Kruger T. (2005). Fluorescence quenching and luminescence sensitization in complexes of $\mathrm{Tb}^{3+}$ and $\mathrm{Eu}^{3+}$ with humic substances. Environmental Science \& Technology 39 (24), 9528-9533; DOI 10.1021/es051437f.

23. Marang L., Reiller P.E., Eidner S., Kumke M.U., and Benedetti M.F. (2008). Combining spectroscopic and potentiometric approaches to characterize competitive binding to humic substances. Environmental Science \& Technology 42 (14), 5094-5098; DOI 10.1021/es702858p.
24. Brevet J., Claret F., and Reiller P.E. (2009). Spectral and temporal luminescent properties of $\mathrm{Eu}(\mathrm{III})$ in humic substance solutions from different origins. Spectrochimica Acta Part A: Molecular and Biomolecular Spectroscopy 74 (2), 446-453; DOI 10.1016/j.saa.2009.06.042.

25. Marang L., Eidner S., Kumke M.U., Benedetti M.F., and Reiller P.E. (2009). Spectroscopic characterization of the competitive binding of $\mathrm{Eu}(\mathrm{III}), \mathrm{Ca}(\mathrm{II})$, and $\mathrm{Cu}(\mathrm{II})$ to a sedimentary originated humic acid. Chemical Geology 264 (1-4), 154-161; DOI 10.1016/j.chemgeo.2009.03.003.

26. Reiller P.E., and Brevet J. (2010). Bi-exponential decay of Eu(III) complexed by Suwannee River humic substances: spectroscopic evidence of two different excited species. Spectrochimica Acta Part A: Molecular and Biomolecular Spectroscopy 75 (2), 629-636; DOI 10.1016/j.saa.2009.11.029.

27. Lukman S., Saito T., Aoyagi N., Kimura T., and Nagasaki S. (2012). Speciation of $\mathrm{Eu}^{3+}$ bound to humic substances by time-resolved laser fluorescence spectroscopy (TRLFS) and parallel factor analysis (PARAFAC). Geochimica et Cosmochimica Acta 88, 199-215; DOI 10.1016/j.gca.2012.04.023.

28. Janot N., Benedetti M.F., and Reiller P.E. (2011). Colloidal $\alpha$ $\mathrm{Al}_{2} \mathrm{O}_{3}$, europium(III) and humic substances interactions: a macroscopic and spectroscopic study. Environmental Science \& Technology 45 (8), 3224-3230; DOI 10.1021/Es102592a.

29. Sonke J.E., and Salters V.J.M. (2006). Lanthanide-humic substances complexation. I. Experimental evidence for a lanthanide contraction effect. Geochimica et Cosmochimica Acta 70 (6), 1495-1506; DOI 10.1016/j.gca.2005.11.017.

30. Sonke J.E. (2006). Lanthanide-humic substances complexation. II. Calibration of humic ion-binding Model V. Environmental Science \& Technology 40 (24), 7481-7487; DOI 10.1021/es060490g.

31. Pourret O., Davranche M., Gruau G., and Dia A. (2007). Rare earth elements complexation with humic acid. Chemical Geology $243 \quad(1-2), \quad 128-141 ; \quad$ DOI 10.1016/j.chemgeo.2007.05.018

32. Pearson R.G. (1963). Hard and soft acids and bases. Journal of the American Chemical Society 85 (22), 3533-3539; DOI 10.1021/ja00905a001.

33. Milne C.J., Kinniburgh D.G., and Tipping E. (2001). Generic NICA-Donnan model parameters for proton binding by humic substances. Environmental Science \& Technology 35 (10), 2049-2059; DOI 10.1021/es000123j

34. Milne C.J., Kinniburgh D.G., van Riemsdijk W.H., and Tipping E. (2003). Generic NICA-Donnan model parameters for metal-ion binding by humic substances. Environmental Science \& Technology 37 (5), 958-971; DOI 10.1021/es0258879. 


\section{Y.Z. KOUHAIL, M.F. BENEDETTI, AND P.E. REILLER}

35. Guillaumont R., Fanghänel T., Fuger J., Grenthe I., Neck V., Palmer D.A., and Rand M. (2003) Chemical Thermodynamics 5. Update on the Chemical Thermodynamics of Uranium, Neptunium, Plutonium, Americium and Technetium. North Holland Elsevier Science Publishers B. V.: Amsterdam, The Netherlands, 2003; Vol. 5, p 918.

36. Dierckx A., Maes A., and Vancluysen J. (1994). Mixed complex formation of $\mathrm{Eu}^{3+}$ with humic acid and a competing ligand. Radiochimica Acta 66/67, 149-156; DOI 10.1524/ract.1994.6667.special-issue.149.

37. Glaus M.A., Hummel W., and van Loon L.R. (1995). Stability of mixed-ligand complexes of metal ions with humic substances and low molecular weight ligands. Environmental Science \& Technology 29 (8), 2150-2153; DOI 10.1021/es00008a039.

38. Panak P., Klenze R., and Kim J.I. (1996). A study of ternary complexes of $\mathrm{Cm}$ (III) with humic acid and hydroxide or carbonate in neutral $\mathrm{pH}$ range by time resolved laser fluorescence spectroscopy. Radiochimica Acta 74 (Issue s1), 141-146; DOI 10.1524/ract.1996.74.special-issue.141.

39. Tipping E., Rey-Castro C., Bryan S.E., and Hamilton-Taylor J. (2002). Al(III) and Fe(III) binding by humic substances in freshwaters, and implications for trace metal speciation. Geochimica et Cosmochimica Acta 66 (18), 3211-3224; DOI 10.1016/S0016-7037(02)00930-4.

40. Weber T., Allard T., Tipping E., and Benedetti M.F. (2006). Modeling iron binding to organic matter. Environmental Science \& Technology 40 (24), 7488-7493; DOI 10.1021/es0607077.

41. Janot N., Reiller P.E., and Benedetti M.F. (2013). Modelling $\mathrm{Eu}(\mathrm{III})$ speciation in a $\mathrm{Eu}(\mathrm{III}) /$ humic acid $/ \alpha-\mathrm{Al}_{2} \mathrm{O}_{3}$ ternary system. Colloids and Surfaces A: Physicochemical and Engineering Aspects 435, 9-15; DOI 10.1016/j.colsurfa.2013.02.052.

42. Pourret O., Davranche M., Gruau G., and Dia A. (2007). Competition between humic acid and carbonates for rare earth elements complexation. Journal of Colloid and Interface Science 305 (1), 25-31; DOI 10.1016/i.jcis.2006.09.020.

43. Stockdale A., and Bryan N.D. (2012). Uranyl binding to humic acid under conditions relevant to cementitious geological disposal of radioactive wastes. Mineralogical Magazine $\quad \mathbf{7 6} \quad$ (8), $\quad 3391-3399 ; \quad$ DOI 10.1180/minmag.2012.076.8.52.

44. Stockdale A., Bryan N.D., Lofts S., and Tipping E. (2013). Investigating humic substances interactions with $\mathrm{Th}^{4+}$, $\mathrm{UO}_{2}{ }^{2+}$, and $\mathrm{NpO}_{2}{ }^{+}$at high $\mathrm{pH}$ : relevance to cementitious disposal of radioactive wastes. Geochimica et Cosmochimica Acta 121, 214-228; DOI 10.1016/j.gca.2013.07.009.

45. Belfiore L.A., McCurdie M.P., and Ueda E. (1993). Polymeric coordination complexes based on cobalt, nickel, and ruthenium that exhibit synergistic thermal properties. Macromolecules $26 \quad$ (25), 6908-6917; $\quad$ DOI $10.1021 / \mathrm{ma} 00077 \mathrm{a} 031$
46. Wieder R.K. (1990). Metal cation binding to sphagnum peat and sawdust: relation to wetland treatment of metal-polluted waters. Water, Air, and Soil Pollution 53 (3-4), 391-400; DOI 10.1007/BF00170751.

47. Piccolo A. (2002). The supramolecular structure of humic substances: a novel understanding of humus chemistry and implications in soil science. Advances in Agronomy 75, 57-134; DOI 10.1016/S0065-2113(02)75003-7.

48. Schaumann G.E., Lang F., and Frank J. Do multivalent cations induce cross-links in DOM precipitates? In Humic SubstancesLinking Structure to Functions, Proceedings of the $13^{\text {th }}$ Meeting of the International Humic Substances Society. Universität Karlsruhe, Karlsruhe, Germany. July 30 - August 4, 2006; pp 941-944.

49. Kunhi Mouvenchery Y., Kučerík J., Diehl D., and Schaumann G.E. (2012). Cation-mediated cross-linking in natural organic matter: a review. Reviews in Environmental Science and Bio/Technology 11 (1), 41-54; DOI 10.1007/s11157-0119258-3.

50. Engebretson R.R., and von Wandruszka R. (1997). The effect of molecular size on humic acid associations. Organic Geochemistry 26 (11), 759-767; DOI 10.1016/S01466380(97)00057-0.

51. Engebretson R.R., and von Wandruszka R. (1998). Kinetic aspects of cation-enhanced aggregation in aqueous humic acids. Environmental Science \& Technology 32 (4), 488-493; DOI 10.1021/es970693s.

52. von Wandruszka R., and Engebretson R.R. (2001) Kinetics of humic acid associations. In Humic Substances and Chemical Contaminants, Clapp C.E., Hayes M.H.B., Senesi N., Bloom P.R., and Jardine P.M., Eds. Soil Science Society of America: Madison, WI, USA, pp 119-126.

53. Plaschke M., Rothe J., Schäfer T., Denecke M.A., Dardenne K., Pompe S., and Heise K.H. (2002). Combined AFM and STXM in situ study of the influence of Eu(III) on the agglomeration of humic acid. Colloids and Surfaces A: Physicochemical and Engineering Aspects 197 (1-3), 245-256; DOI 10.1016/S0927-7757(01)00901-3.

54. Plaschke M., Rothe J., Denecke M.A., and Fanghänel T. (2004). Soft X-ray spectromicroscopy of humic acid europium(III) complexation by comparison to model substances. Journal of Electron Spectroscopy and Related Phenomena 135 (1), 53-62; DOI 10.1016/j.elspec.2003.12.007.

55. Naber A., Plaschke M., Rothe J., Hofmann H., and Fanghänel T. (2006). Scanning transmission X-ray and laser scanning luminescence microscopy of the carboxyl group and $\mathrm{Eu}(\mathrm{III})$ distribution in humic acid aggregates. Journal of Electron Spectroscopy and Related Phenomena 153 (3), 71-74; DOI 10.1016/j.elspec.2006.06.005.

56. MacCarthy P. (2001). The principles of humic substances. Soil Science 166 (11), 738-751; DOI 10.1097/00010694-20011100000003. 


\section{Y.Z. KOUHAIL, M.F. BENEDETTI, AND P.E. REILLER}

57. Monsallier J.-M., Scherbaum F.J., Buckau G., Kim J.-I., Kumke M.U., Specht C.H., and Frimmel F.H. (2001). Influence of photochemical reactions on the complexation of humic acid with europium (III). Journal of Photochemistry and Photobiology A: Chemistry 138 (1), 55-63; DOI S10106030(00)00380-4.

58. Carnall W.T., Fields P.R., and Rajnak K. (1968). Electronic energy levels of the trivalent lanthanide aquo ions. IV. $\mathrm{Eu}^{3+}$. The Journal of Chemical Physics 49 (10), 4450-4455; DOI 10.1063/1.1669896.

59. Jørgensen C.K., and Judd B.R. (1964). Hypersensitive pseudoquadrupole transitions in lanthanides. Molecular Physics 8 (3), 281-290; DOI 10.1080/00268976400100321.

60. Dobbs J.C., Susetyo W., Knight F.E., Castles M.A., Carreira L.A., and Azarraga L.V. (1989). A novel-approach to metalhumic complexation studies by lanthanide ion probe spectroscopy. International Journal of Environmental Analytical Chemistry 37 (1), 1-17; DOI 10.1080/03067318908026880.

61. Keizer M.G., and van Riemsdijk W.H. A Computer Program for the Calculation of Chemical Speciation and Transport in Soil-Water Systems (ECOSAT 4.7); Wageningen Agricultural University: Wageningen, The Netherlands, 1994.

62. Benedetti M.F., van Riemsdijk W.H., and Koopal L.K. (1996). Humic substances considered as a heterogeneous Donnan gel phase. Environmental Science \& Technology 30 (6), 1805-1813; DOI 10.1021/es950012y.

63. Hummel W., Berner U., Curti E., Pearson F.J., and Thoenen T. Nagra/PSI Chemical Thermodynamic Data Base 01/01; NTB 02-06; NAGRA: Parkland, FL, USA, 2002.

64. Plancque G., Maurice Y., Moulin V., Toulhoat P., and Moulin C. (2005). On the use of spectroscopic techniques for interaction studies, Part I: complexation between europium and small organic ligands. Applied Spectroscopy 59 (4), 432-441.

65. Barkleit A., Kretzschmar J., Tsushima S., and Acker M. (2014). Americium(III) and europium(III) complex formation with lactate at elevated temperatures studied by spectroscopy and quantum chemical calculations. Dalton Transactions 43 (29), 11221-11232; DOI 10.1039/C4DT00440J.

66. Moreau P., Colette-Maatouk S., Vitorge P., Gareil P., and Reiller P.E. (2015). Complexation of europium(III) by hydroxybenzoic acids: a time-resolved luminescence spectroscopy study. Inorganica Chimica Acta 432, 81-88; DOI 10.1016/j.ica.2015.03.036.

67. Marmodée B., de Klerk J.S., Ariese F., Gooijer C., and Kumke M.U. (2009). High-resolution steady-state and timeresolved luminescence studies on the complexes of $\mathrm{Eu}(\mathrm{III})$ with aromatic or aliphatic carboxylic acids. Analytica Chimica Acta 652 (1-2), 285-294; DOI 10.1016/j.aca.2009.06.006.
68. Kuke S., Marmodée B., Eidner S., Schilde U., and Kumke M.U. (2010). Intramolecular deactivation processes in complexes of salicylic acid or glycolic acid with $\mathrm{Eu}(\mathrm{III})$. Spectrochimica Acta Part A: Molecular and Biomolecular Spectroscopy 75 (4), 1333-1340; DOI 10.1016/j.saa.2009.12.080.

69. Szabó G., Guczi J., Reiller P.E., Miyajima T., and Bulman R. (2010). Effect of ionic strength on complexation of $\mathrm{Pu}$ (IV) with humic acid. Radiochimica Acta 98 (1), 13-18; DOI 10.1524/ract.2010.1683.

70. Hummel W., Glaus M., and van Loon L. (2000). Trace metalhumate interactions. II. The "conservative roof" model and its application. Applied Geochemistry 15 (7), 975-1001; DOI 10.1016/S0883-2927(99)00100-6.

71. Kinniburgh D.G., Milne C.J., Benedetti M.F., Pinheiro J.P., Filius J., Koopal L.K., and van Riemsdijk W.H. (1996). Metal ion binding by humic acid: application of the NICA-Donnan model. Environmental Science \& Technology 30 (5), 1687-1698; DOI 10.1021/es950695h.

72. Caceci M.S. (1985). The interaction of humic acid with europium (III). Complexation strength as a function of load and $\mathrm{pH}$. Radiocbimica Acta 39 (1), 51-56; DOI 10.1524/ract.1985.39.1.51.

73. Bertha E.L., and Choppin G.R. (1978). Interaction of humic and fulvic acids with $\mathrm{Eu}(\mathrm{III})$ and $\mathrm{Am}(\mathrm{III})$. Journal of Inorganic and Nuclear Chemistry 40 (4), 655-658; DOI 10.1016/00221902(78)80382-0.

74. Torres R.A., and Choppin G.R. (1984). Europium(III) and americium(III) stability constants with humic acid. Radiochimica Acta $35 \quad$ (3), 143-148; $\quad$ DOI 10.1524/ract.1984.35.3.143.

75. Lyklema J. (1995) Fundamentals of Colloid and Interface Science, Volume I: Fundamentals. Academic Press Ltd: London, UK, 1995; Vol. I.

76. Domingos R.F., Tufenkji N., and Wilkinson K.J. (2009). Aggregation of titanium dioxide nanoparticles: role of a fulvic acid. Environmental Science \& Technology 43 (5), 1282-1286; DOI $10.1021 /$ es 8023594 .

77. d'Orlyé F., and Reiller P.E. (2012). Contribution of capillary electrophoresis to an integrated vision of humic substances size and charge characterizations. Journal of Colloid and Interface Science 368 (1), 231-240; DOI 10.1016/j.jcis.2011.11.046.

78. Blaakmeer J., Böhmer M.R., Cohen Stuart M.A., and Fleer G.J. (1990). Adsorption of weak polyelectrolytes on highly charged surfaces: poly(acrylic acid) on polystyrene latex with strong cationic groups. Macromolecules 23 (8), 2301-2309; DOI $10.1021 / \mathrm{ma} 00210 \mathrm{a} 028$

79. Böhmer M.R., Evers O.A., and Scheutjens J.M.H.M. (1990). Weak polyelectrolytes between 2 surfaces: adsorption and stabilization. Macromolecules 23 (8), 2288-2301; DOI $10.1021 / \mathrm{ma} 00210 \mathrm{a} 027$. 


\section{Y.Z. KOUHAIL, M.F. BENEDETTI, AND P.E. REILLER}

80. Weng L.P., van Riemsdijk W.H., and Hiemstra T. (2007). Adsorption of humic acids onto goethite: effects of molar mass, $\mathrm{pH}$ and ionic strength. Journal of Colloid and Interface Science 314 (1), 107-118; DOI 10.1016/j.jcis.2007.05.039.

81. Weng L.P., van Riemsdijk W.H., and Hiemstra T. (2006). Adsorption free energy of variable-charge nanoparticles to a charged surface in relation to the change of the average chemical state of the particles. Langmuir 22 (1), 389-397; DOI 10.1021/la051730t.
82. Saito T., Nagasaki S., Tanaka S., and Koopal L.K. (2005). Electrostatic interaction models for ion binding to humic substances. Colloids and Surfaces A: Physicochemical and Engineering Aspects 265 (1-3), 104-113; DOI 10.1016/j.colsurfa.2004.10.139.

83. Saito T., Koopal L.K., Nagasaki S., and Tanaka S. (2009). Electrostatic potentials of humic acid: fluorescence quenching measurements and comparison with model calculations. Colloids and Surfaces A: Physicochemical and Engineering Aspects 347 (1-3), 27-32; DOI 10.1016/j.colsurfa.2008.10.038. 
Y.Z. KOUHAIL, M.F. BENEDET'TI, AND P.E. REILLER

YASMINE Z. KOUHAIL

Institut de PhysiQue du Globe de Paris, Sorbonne Paris Cité

UNIVERSITÉ PARIS DIDEROT, UMR 7154 CNRS

F-75005 PARIS, FRANCE

MARC F. BENEDETTI

Institut de Physique du Globe de PARIS, Sorbonne Paris Cité

UNIVERSITÉ PARIS DIDEROT, UMR 7154 CNRS

F-75005 PARIS, FRANCE

PASCAL E. REILLER

COMMISSARIAT À L'ÉNERGIE ATOMIQUE ET AUX ÉNERGIES ALTERNATIVES DEN, DANS, DPC, LABORATOIRE DE DÉVELOPPEMENT ANALYTIQUE NUCLÉAIRE ISOTOPIQUE ET ÉLÉMENTAIRE, AND UNIVERSITÉ PARIS-SACLAY, DÉPARTEMENT DE CHIMIE

CE CEA SACLAY, BÂTIMENT 391 PC 33

F-91191 Gif-SUR-Yvette CedeX, FranCE 